\title{
Tranparansi dan Akuntabilitas Pelaporan Keuangan Masjid Agung Al-Akbar Surabaya
}

\author{
Ruci Arizanda Rahayu \\ Program Magister Akuntansi, Pascasarjana FEB, Universitas Brawijaya \\ e-mail: icha.bie91@gmail.com
}

\begin{abstract}
This study is conducted to understand the meaning of transparency and accountability financial report of Surabaya Al Akbar national Mosque. This study is a descriptive qualitative study while the study approach is phenomenological transcendental by taking site and location at Surabaya Al Akbar National Mosque. Data is gained by interview to 12 (twelve) informant keys as communities, donor, administrative section head, treasury, secretary, and mosque staff. Data validity testing is taken by triangulation technique and analysis method is taken by intentional analysis, epoche, and eidetic reduction steps. The result of the study concludes that Surabaya Al Akbar National Mosque in applying accountancy uses the basic standard PSAK nu. 45 year 2011 about nonprofit organization including financial position report, activities report, money supply report, and notes for financial report. Applying this practice is guaranteed by good faith quality values as amanah, istiqomah, uswah, mas'uliah, and liljami'il-ummah as behavior orientation for the mosque organizer, skillfully human resources in organization structure, community role, and the acknowledgment by quality management system ISO 9001:2008. Accountability principal is part of worship by vertical and horizontal responsibility pattern. The vertical pattern to supervisor agency, East Java Government, and Allah SWT to get His blessing. The horizontal pattern is tended to mosque donor and society. Transparency principal is done by providing clear information about the procedures, costs, and responsibility of the mosque organizer agency and giving ease access to financial report information, complaint mechanism arrangement, and improving information through cooperation with public medium. However, financial report has not checked yet by independent auditor so, it is lessening the value of accountability and transparency financial report itself.
\end{abstract}

Keyword: accountability, Allah's blessing, informant, interview, phenomenological, transparency.

\section{PENDAHULUAN}

Organisasi keagamaan merupakan organisasi nirlaba, karena organisasi ini didirikan tidak bertujuan untuk memperoleh laba. Mengingat semakin berkembangnya umat Islam dan masjid di Indonesia, maka dana yang dibutuhkan untuk mendukung segala aktivitas dan biaya operasional masjid menjadi tidak sedikit jumlahnya. Dana-dana tersebut diperlukan untuk mendukung kegiatan peribadatan, keagamaan, sarana dan prasarana, serta pembangunan dan pembenahan masjid itu sendiri, sehingga sudah sepantasnya masjid sebagai organisasi nirlaba juga memperhatikan masalah pencatatan dan pelaporan keuangan.

Akuntabilitas keuangan organisasi masjid bersandar pada kekuatan sistem pengendalian internal dan kinerja pengelolaan keuangan organisasi, yang harus dikembangkan secara spesifik sesuai karakteristik khusus organisasi masjid. Penaksiran resiko dan penentuan aktivitas pengendalian akan menjadi kunci utama bagi pengembangan sebuah sistem pengendalian internal. Akuntabilitas keuangan organisasi nirlaba juga akan sangat ditentukan oleh beberapa faktor pendukung kinerja pengolahan yang lain, yaitu sumber daya manusia, infraksturktur, dan perangkat pengelolaan keuangan. Keseluruhan elemen ini harus dipahami dan dikembangkan secara sistematis, sebagai salah satu upaya mempertahankan keberlanjutan organisasi dan pada akhirnya, sebagai bagian dari upaya memperkuat posisi dan peran masyarakat sipil di Indonesia.

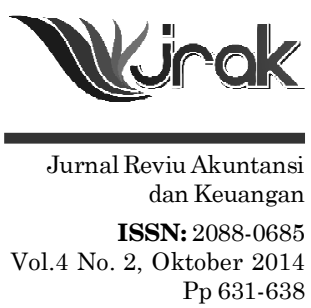


Tranparansi

dan

Akuntabilitas

Pelaporan...

632
Masjid merupakan organisasi nirlaba harus dan berhak untuk membuat laporan dan melaporkannya kepada para pemakai pihak-pihak yang berkepentingan. Hal ini sudah sewajarnya mengingat hidup dan berkembangnya organisasi masjid bersumber dari sumbangan, sedekah, atau bentuk bantuan sosial lainnya. Organisasi harus membuka diri terhadap hak masyarakat umum untuk memperoleh informasi yang benar, jujur, dan tidak diskriminatif, setidak-tidaknya terhadap anggota organisasi keagamaan tersebut. Informasi dapat diakses oleh siapa saja dengan menggunakan mekanisme tertentu, sehingga tidak disalahgunakan oleh pihak-pihak yang berniat buruk terhadap organisasi. Konsekuensi ini menjadi sebuah kewajiban yang harus dipenuhi karena kemampuan untuk dapat mempertanggungjawabkan organisasi masjid akan sangat mempengaruhi tingkat kepercayaan masyarakat terhadap organisasi masjid itu sendiri.

Sebagian masyarakat termasuk didalamnya para pengurus masjid atau ta'mir masjid memiliki menyampaikan informasi keuangan yang berhubungan dengan laporan penyumbang (jumlah disumbangkan) kepada publik (jamaah) karena dianggap akan merusak nilai keikhlasan bagi para donatur yang memberikan sumbangan semata mencari ridho Allah SWT. Namun demikian tak jarang sebagian masyarakat yang lain memandang perlunya laporan siapa dan jumlah sumbangan yang masuk dari donator, agar informasi mengenai posisi keuangan secara jelas, transparan dan dapat dipertanggungjawabkan. Situasi dilematis seperti ini menyebabkan para pengurus pada akhirnya merasa tidak perlu menyampaikan laporan penyumbang.

Masjid Nasional Al Akbar Surabaya merupakan salah satu masjid yang cukup terkenal di Kota Surabaya bukan saja karena letaknya yang strategis di pusat kota dan kemegahan bangunannya namun lebih dari itu masjid ini memiliki visi mengembangkan diri sebagai masjid yang juga memberikan layanan dan solusi kebutuhan umat. Masjid Nasional Al Akbar Surabaya merupakan masjid bertaraf nasional dengan visi pengembangan dakwah dan syiar islam, pendidikan, sosial budaya dan manajemen handal menuju masyarakat yang berakhlakul karimah sesuai ajaran islam. Untuk mewujudkan visi tersebut, maka diterapkan prinsip manajemen ikhlas professional yang bermakna bahwa semua pekerjaan berorientasi ibadah dengan tenaga yang ahli dibidangnya. Para jamaah diharapkan tidak hanya sekedar memenuhi urusan ritual ibadah saja, namun juga menjadi sentra pembangunan potensi ekonomi umat sebagaimana Masjid Nabawi pada jaman Nabi, menjadi sentra solutif bagi umat.

Atas dasar pemahaman visi dan misi Masjid Nasional Al Akbar Surabaya ini sudah barang tentu keberadaan keuangan masjid juga menjadi prioritas atau bagian yang harus selalu dikedepankan dalam pengelolaannya. Pengelolaan dimaksud tidak saja dari sisi penggalangan dan penggunaannya, namun juga dari sisi pelaporan keuangannya. Sudah semestinya pula jika Masjid Nasional Al Akbar Surabaya akan selalu melaporkan kondisi keuangannya secara periodik dengan tetap mengedepankan transparansi dan akuntabilitasnya. Hal ini tentunya sejalan pula dengan upaya pengelolaan Masjid Nasional Al Akbar Surabaya yang berorientasi pada ibadah semata-mata mencari ridha Allah SWT.

Organisasi masjid sering menjadi sorotan masyarakat terkait keterbukaan mengenai dana sumbangan yang diberikan oleh para donatur, sehingga sudah semestinya pengelola masjid melakukan pelaporan keuangan secara periodik, transparan, dan akuntabel. Kredibilitas organisasi masjid ini tentunya akan mampu meningkatkan kepercayaan masyarakat yang akan membuka peluang bertambahnya jumlah pemberi sumbangan. Atas dasar paparan ini maka tujuan penelitian ini adalah untuk memahami makna transparansi dan akuntabilitas laporan keuangan Masjid Nasional Al-Akbar Surabaya. 
Pendekatan kualitatif atau paradigma alamiah naturalistic paradigm dipilih dalam penelitian ini dipilih karena penelitian kualitatif merupakan metode untuk mengeksplorasi dan memahami makna permasalahan sosial. Penelitian ini menggunakan paradigma interpretif. Paradigma interpretif menurut Burrel dan Morgan (1979) dalam Triyuwono (2006) merupakan paradigma yang mempunyai gagasan filosofi maupun sosiologi untuk memahami dan menjelaskan dunia sosial dari sudut pandang pelaku yang bersinggungan dengan fenomena yang terjadi.

Paradigma interpretif dalam penelitian ini berusaha untuk mengungkap trasparansi dan akuntabilitas Masjid Nasional Al Akbar Surabaya sebagai realitas sosial yang dibentuk dan dipertahankan oleh individu tertentu serta dan bagaimana mereka memaknainya. Secara umum penelitian ini berupaya untuk mendapatkan pemahaman yang mendalam mengenai makna transparansi dan akuntabilitas organisasi Masjid Nasional Al Akbar Surabaya dalam bentuk realitas yang sesungguhnya berupa laporan keuangan.

Peneliti menggunakan fenomenologi transendental dari Husserl (2001) sebagai pendekatan terhadap aktivitas yang dilakukan oleh Masjid Nasional Al-Akbar Surabaya. Terkait hal ini peneliti berupaya mempelajari struktur tipe-tipe kesadaran yang terdiri dari persepsi, gagasan, memori, imajinasi, pengalaman langsung dari informan melalui kesadaran. Peneliti akan berupaya mendiskripsikan obyek dengan melakukan pendekatan terus-menerus dengan pihak-pihak yang berkepentingan dengan transparansi dan akuntabilitas keuangan Masjid Nasional Al-Akbar Surabaya.

Informan dalam penelitian ini terdiri dari informan dan key informan. Informan adalah orang yang dimanfaatkan untuk memberikan informasi tentang situasi dan kondisi latar penelitian (Moleong, 2006). Penentuan informan kunci dilakukan secara sampling purposive, yaitu teknik yang mencakup orang-orang yang diseleksi atas dasar kriteria tertentu. Teknik ini dipilih untuk penelitian yang lebih mengutamakan kedalaman data, daripada untuk tujuan represetatif yang dapat digeneralisasikan (Krisyanto, 2007).

Key informan merupakan informan yang mampu memberikan keteranganketerangan yang berhubungan dengan transparansi dan akuntabilitas pelaporan keuangan Masjid Nasional Al-Akbar Surabaya. Key informan sebanyak 12 (dua belas) orang dengan status jamaah, donatur, Kepala Bagian, Kepala Bidang, Bendahara, Sekretaris, dan Karyawan Masjid.

Data yang diperlukan dalam penelitian secara garis besar terdiri dari data sekunder dan data primer. Data sekunder berasal dari dokumentasi peneliti seperti hasil pemotretan melalui observasi atas lokasi penelitian; dokumentasi wawancara dengan informan kunci; dokumen-dokumen hasil wawancara dan buku-buku serta tulisan penelitian sebelumnya. Sementara itu, data primer diperoleh langsung dari subyek atau informan kunci dalam bentuk verbal atau perkataan tentang pemahaman, pandangan, pemikiran, pengalaman, dan perasaan informan kunci tentang transparansi dan akuntabilitas laporan keuangan Masjid Nasional AlAkbar Surabaya. Adapun metode pengumpulan data baik data primer dan data sekunder dalam penelitian ini adalah (1) wawancara mendalam (indept interview), (2) observasi partisipan (participant observation), dan (3) studi dokumentasi (study of document).

Terdapat beberapa macam triangulasi yang dilakukan dalam penelitian ini yaitu: (1) triangulasi data, dilakukan dengan dua cara, yaitu data antar waktu untuk masing-masing situs dan situs. Data antar waktu dilakukan dengan cara mencocokkan ungkapan verbal yang diperoleh dari hasil wawancara mendalam dengan masing-masing informan dari waktu ke waktu untuk menghasilkan informasi yang konsisiten. Triangulasi antara situs, peneliti memadukan dan meng- 
Tranparansi dan Akuntabilitas Pelaporan... 634 analisis informasi yang diperoleh dari informan untuk menemukan kecocokan tematema yang muncul; (2) triangulasi teori dilakukan dengan membandingkan hasil yang diperoleh di lapangan dengan teori yang sudah ada; dan (3) triangulasi teknik pengambilan data dilakukan dengan cara menyelaraskan hasil yang diperoleh dari teknik pengumpulan data dengan cara indepth-interview, observasi dan dukungan dokumentasi.

Tahap-tahap analisis dalam pendekatan fenomenologi penelitian ini dilakukan dengan tahapan Intentional analysis, Epoche, dan Eidetic Reduction. Intentional analysis, peneliti menggabungkan antara obyek yang dipersepsikan (noema) dan pemahaman subjekif (noesis) pada obyek penelitian melalui catatan, laporan laporan, persepsi individu yang kompeten dengan permasalahan transparansi dan akuntabilitas laporan keuangan Masjid Nasional Al-Akbar Surabaya.

Epoche, peneliti menggali informasi sebanyak-banyaknya kepada para informan untuk menggali data terkaqit transparansi dan akuntabilitas laporan keuangan Masjid Nasional Al-Akbar Surabaya dalam pelaporan keuangan Masjid Nasional Al-Akbar Surabaya. Peneliti tetap berusaha konsisten membawa subjek pada informasi-informasi yang berhubungan dengan transparansi dan akuntabilitas laporan keuangan Masjid Nasional Al-Akbar Surabaya.

Eidetic Reduction, peneliti melakukan pemilahan hal-hal penting dan tidak penting sebagai acuan berikutnya dalam melakukan pembahasan. Artinya, data yang telah terkumpul dilakukan inventarisir (penyaringan) sesuai kebutuhan penelitian yang dalam hal ini yang berhubungan dengan transparansi dan akuntabilitas laporan keuangan Masjid Nasional Al-Akbar Surabaya.

\section{HASIL DAN PEMBAHASAN}

\section{Akuntansi Masjid Bukan Impian}

Pembicaraan tentang organisasi masjid tentu tidak bisa lepas dari keberadaan nilai-nilai Islam berikut segala bentuk aktivitas keislaman yang ada di di dalamnya. Hal ini disukai atau tidak keberadaan akuntansi dalam sebuah organisasi masjid akan memunculkan nilai-nilai Islam ke permukaan sebagai panduan perilaku bagi para pelaku akuntansi. Nilai-nilai Islam akan menjadi batas-batas yang akan memunculkan rasa takut terhadap dosa ketika para pelaku akuntansi berniat kurang baik dalam mengelola dana umat. Hingga kemudian justru akuntansi akan menjadi alat (tool) dan bumbu penyedap dalam meningkatkan ketaqwaan kepada Alloh SWT. Hal inilah yang sebenarnya diharapkan akan terwujud pada organisasi masjid secara keseluruhan dan khususnya di entitas Masjid Nasional Al Akbar Surabaya.

Pernyataan terkait peran akuntansi dalam Islam merupakan alat (tool) dalam meningkatkan ketaqwaan kepada Alloh SWT. Allah pun menurunkan Surat AlBaqarah Ayat 282 yang mengandung substansi kejujuran dalam hal transaksi keuangan. Demikian arti dari Al-Qur'an Surat Al-Baqarah Ayat 282. Kandungan Al-Qur'an dalam Surat Al-Baqarah ayat 282 mencerminkan bahwa akuntansi dalam Islam bukanlah yang baru. Akuntansi penting digunakan untuk menjadikan kegiatan keagamaan menjadi lebih baik seperti di tempat ibadah (masjid) dan pasar perdagangan. Muamalah itu sendiri berasal dari kata aamala, yuamilu, muamalat yang berarti perlakuan atau tindakan terhadap orang lain, hubungan kepentingan (Bek, 2009). Muamalah adalah hukum-hukum syara' yang berkaitan dengan urusan dunia dan kehidupan manusia, seperti jual beli, perdagangan, dan lain sebagainya (Munawwir, 2003).

Masjid Nasional Al Akbar Surabaya dalam pengelolaan keuangan jelas-jelas membutuhkan akuntansi. Penerapan akuntansi diharapkan mampu memberikan informasi keuangan untuk kepentingan pengambilan keputusan demi kemajuan dan perkembangan Masjid Nasional Al Akbar Surabaya. Selain itu, informasi 
keuangan ini sekaligus sebagai tolak ukur kinerja para pengurus masjid. Hingga saat ini, penerapan akuntansi di Masjid Nasional Al Akbar Surabaya tidak mengalami masalah dan berjalan sebagaimana yang diharapkan bersama terbukti dengan adanya laporan penerimaan dan pengeluaran dana atau kas yang tertata dengan baik. Pernyataan terkait adanya laporan penerimaan dan pengeluaran dana atau kas yang tertata dengan baik tentunya tidak bisa mewakili bahwa penerapan akuntansi Masjid Nasional Al Akbar Surabaya telah berjalan dengan baik secara keseluruhan. Praktik akuntansi haruslah accountable dan transparant, apalagi pada organisasi masjid seperti Masjid Nasional Al Akbar Surabaya.

Masjid Nasional Al Akbar Surabaya merupakan organisasi nirlaba yang harus menggunakan standar-standar atau kaidah-kaidah tertentu dalam menyusun laporan keuangan. Masjid Nasional Al Akbar Surabaya tentunya tidak ingin menjadi bagian dari organisasi-organisasi masjid lainnya yang kebanyakan hanya menyampaikan laporan keuangan sangat sederhana. Tak jarang, laporan keuangan organisasi masjid hanya berbentuk saldo harian untuk mencatat keluar masuk uang secara harian untuk kemudian disusun dalam bentuk laporan keuangan bulanan. Hal ini tentunya kurang mampu memberikan informasi secara jelas dan tegas kepada masyarakat terkait kondisi keuangan masjid yang bersangkutan. Kurangnya informasi yang bisa disampaikan oleh laporan keuangan yang sangat sederhana ini tidak menutup kemungkinan akan memunculkan prasangka dan fitnah terhadap para pengurus masjid terkait penggunaan dana.

Pelaporan keuangan Masjid Nasional Al Akbar Surabaya, tentu saja telah menggunakan standar baku sebagaimana diatur dalam Pernyataan Standar Akuntansi Keuangan (PSAK) No. 45 Tahun 2011 tentang Organisasi Nirlaba. Praktek penyusunan laporan keuangan berupaya memberikan informasi keuangan melalui komponen-komponen sebagaimana diatur dalam PSAK 45. Sekalipun dalam pelaksanaan penyusunan laporan keuangan dibantu Program aiSoft namun komponen-komponen laporan keuangan Masjid Nasional Al Akbar Surabaya telah mencakup laporan posisi keuangan, laporan aktivitas, laporan arus kas, dan catatan atas laporan keuangan.

Siklus akuntansi Masjid Nasional Al Akbar Surabaya tersebut menunjukkan adanya aktivitas pencatatan adalah proses mencatat seluruh transaksi atau kejadian ekonomi yang terjadi Masjid Nasional Al Akbar Surabaya. Dalam proses ini, pecatatan dilakukan di dalam media yang disebut sebagai buku harian atau jurnal harian. Penggolongan merupakan proses mengelompokkan transaksi yang terjadi di Masjid Nasional Al Akbar Surabaya yang mempunyai akun atau rekening yang sama ke dalam buku besar dan buku pembantu. Peringkasan itu proses meringkas atau memasukkan saldo-saldo dari buku besar/buku pembantu ke dalam neraca lajur untuk mempermudah kerja penyusunan laporan keuangan dan juga meminimalisir kesalahan-kesalahan pencatatan setelah dilakukan penyesuaian yang dilakukan setiap akhir periode. Pelaporan merupakan proses memindahkan transaksi yang ada di dalam neraca lajur ke dalam format standar akuntansi, yakni laporan posisi keuangan (neraca), laporan aktivitas, laporan arus kas, dan catatan atas laporan keuangan.

\section{Akuntabilitas Dan Transparansi Sebagai Bagian Dari Ibadah}

Keberadaan masjid tidak bisa dilepaskan dari pengelolaan dana yang berasal dari amal atau sumbangan umat yang tidak mengharapkan imbalan apapun dari organisasi tersebut. Namun demikian, tidak berarti masyarakat tidak mementingkan pertanggungjawaban dan transparansi dari pengurus organisasi keagamaan. Pada kondisi inilah akuntabilitas dan transparansi menjadi penting bagi Masjid Nasional Al Akbar Surabaya.

Akuntabilitas dan transparansi keuangan dalam pengelolaan keuangan khususnya organisasi masjid tidak bisa lepas dari peran para pelaku akuntansi itu sendiri. Manusia sebagai pelaku akuntansi memiliki peran mutlak untuk menjadikan sebuah laporan keuangan itu benar-benar jujur atau sebaliknya, terdapat 
Tranparansi dan Akuntabilitas Pelaporan...

636 kecurangan. Keduanya merupakan sebuah pilihan, keduanya sama-sama memiliki peluang untuk terjadi. Bahkan, tak jarang memunculkan godaan bagi para pelaku akuntansi hingga terjadi dilema batin ketika mulai ada niatan untuk berbuat kecurangan. Kecurangan laporan keuangan sering juga dikenal dengan istilah kecurangan manajemen karena secara umum kecurangan ini dilakukan oleh pihak manajemen dan tak jarang hal ini terjadi tanpa sepengetahuan para karyawan. Manajemen berada pada posisi yang strategis dalam membuat keputusan akuntansi dan pelaporan tanpa harus sepengetahuan para karyawan.

Masjid Nasional Al Akbar Surabaya menetapkan nilai-nilai aqidah Islam sebagai Pedoman Tingkah Laku Karyawan Masjid Nasional Al Akbar Surabaya. Nilai yang dijadikan pedoman adalah Amanah, Istiqomah, Uswah, Mas'uliah dan Li jami' il-Ummah.Amanah memiliki pengertian bahwa pengurus dipercaya dalam mengemban visi Masjid Nasional Al Akbar Surabaya sebagai masjid yang Menjadi rujukan nasional dalam da'wah, ibadah, pendidikan dan manajemen menuju masyarakat madani. Uswah adalah menjadi teladan masjid lain dalam berbagai aspek mas'uliah memberikan pemaknaan bahwa setiap langkah dan keputusan para pengurus Masjid Nasional Al Akbar Surabaya dapat dipertanggungjawabkan di hadapan Allah, umat dan para stakeholders. Makna Li jami' il-Ummah merujuk pada pengertian bahwa setiap praktek ibadah dapat diterima oleh semua umat Islam, sesuai syara' dan peraturan perundangan yang berlaku.

Kenyataan menunjukkan bahwa hampir belum pernah terjadi kecurangan laporan keuangan, baik yang dilakukan dengan sengaja atau tidak sengaja, baik di tingkatan jajaran direksi (manajemen) maupun di kalangan karyawan Masjid Nasional Al Akbar Surabaya. Hal ini merupakan pembuktian adanya kesadaran para pengurus dalam perannya sebagai pengemban amanah umat untuk mengelola dana secara benar.

Pola pertanggungjawaban Masjid Nasional Al Akbar Surabaya bersifat vertikal dan horizontal. Pertanggungjawaban vertikal adalah pertanggungjawaban pengelolaan dana kepada otoritas yang lebih tinggi, yakni Badan Pengawas Masjid Nasional Al Akbar Surabaya dan Pemerintah Provinsi Jawa Timur. Sementara dalam konteks yang lebih jauh, pertanggungjawaban secara vertikal merupakan pertanggungjawaban kepada Allah SWT. Sedangkan pertanggungjawaban horizontal adalah pertanggungjawaban kepada masyarakat luas, khususnya pengguna atau penerima layanan Masjid Nasional Al Akbar Surabaya. Kedua pola pertanggungjawaban tersebut merupakan elemen penting dari proses akuntabilitas publik.

Upaya yang dilakukan Masjid Nasional Al Akbar Surabaya dalam meningkatkan transparansi paling tidak dapat diukur melalui sejumlah indikator seperti pertama, penyediaan informasi yang jelas tentang prosedur-prosedur, biaya-biaya dan tanggung jawab. Kedua, kemudahan akses informasi. Ketiga, menyusun suatu mekanisme pengaduan jika ada peraturan yang dilanggar, dan keempat meningkatkan arus informasi melalui kerjasama dengan media massa dan lembaga non pemerintahan. Prinsip transparansi masjid tidak hanya menyediakan dan memberikan informasi mengenai masjid yang ada. Mekanisme dan peraturan yang jelas untuk mendapatkan informasi dibuat sebagaimana mestinya guna meningkatkan prinsip transparansi itu sendiri.

Realitas menunjukkan bahwa selama ini laporan keuangan Masjid Nasional Al Akbar Surabaya belum pernah dilakukan pemeriksaan oleh auditor independen. Hal ini sudah barangtentu mengurangi nilai akuntabilitas laporan keuangan Masjid Nasional Al Akbar Surabaya. Meskipun audit terhadap masjid dilakukan hanya sebatas pada kegiatan pembangunan dan renovasinya, akan tetapi tidak ada salahnya ketika pelaksanaan audit tersebut diterapkan untuk mengaudit aktivitas keuangan masjid karena tidak menutup kemungkinan adanya penyelewengan dana yang dilakukan oleh beberapa oknum pengurus masjid yang kurang bertanggung jawab. Oleh karena itu adanya audit masjid ini akan mengungkap apabila terjadi penyelewengan dana, kalaupun tidak ditemukan adanya penye- 
lewengan dana masjid, setidaknya akan memberikan transparansi pengelolaan dana sehinggan akan meningkatkan kepercayaan masyarakat terhadap ta'mir masjid tersebut.

\section{SIMPULAN}

Atas dasar pembahasan pada bab-bab sebelumnya maka dapat ditarik kesimpulan bahwa Masjid Nasional Al Akbar Surabaya dalam praktek akuntansi menggunakan standar baku sebagaimana diatur dalam Pernyataan Standar Akuntansi Keuangan (PSAK) No. 45 Tahun 2011 tentang Organisasi Nirlaba. Laporan keuangan meliputi laporan posisi keuangan, laporan aktivitas, laporan arus kas, dan catatan atas laporan keuangan.

Perilaku praktek akuntansi Masjid Nasional Al Akbar Surabaya dijamin oleh kualitas keimanan yang baik yang didukung oleh struktur organisasi yang diisi oleh sumberdaya manusia kompeten. Kualitas keimanan yang mempengaruhi praktek akuntansi ini berangkat dari penetapan nilai-nilai Amanah, Istiqomah, Uswah, Mas'uliah dan Li jami' il-Ummah sebagai Pedoman Perilaku bagi para Pengelola Masjid. Prinsip Akuntabilitas dalam praktek akuntansi Masjid Nasional Al Akbar Surabaya dipandang sebagai bagian dari ibadah. Pola pertanggungjawaban bersifat vertikal, yakni kepada Badan Pengawas Masjid Nasional Al Akbar Surabaya, Pemerintah Provinsi Jawa Timur, dan Allah SWT sebagai upaya mendapatkan ridho-Nya, sedangkan pertanggungjawaban horizontal kepada para donator masjid dan masyarakat.

Penerapan transparansi laporan keuangan Masjid Nasional Al Akbar Surabaya dilakukan dengan menyediakan informasi yang jelas tentang prosedurprosedur, biaya-biaya, dan tanggung jawab Badan Pengelola Masjid, pemberian kemudahan akses informasi laporan keuangan, penyusunan mekanisme pengaduan jika terjadi pelanggaran peraturan yang dilanggar, dan peningkatan arus informasi melalui kerjasama dengan media massa dan lembaga non-pemerintahan. Namun demikian, laporan keuangan Masjid Nasional Al Akbar Surabaya belum pernah dilakukan pemeriksaan oleh auditor independen yang tentunya mengurangi nilai akuntabilitas laporan keuangan Masjid Nasional Al Akbar Surabaya.

\section{DAFTAR PUSTAKA}

Anonymous. 2012. Al-Qur'anul Karim: Tafsir Kata Tajwid Kode. The Holy Qur'an Al Fatih. Terjemahan Surat Al-Baqarah Ayat 262 dan Ayat 264. Al-Fatih. Jakarta.

Anonymous. 2012. Al-Qur'anul Karim: Tafsir Kata Tajwid Kode. The Holy Qur'an Al Fatih. Terjemahan Surat Al-Baqarah Ayat 282. Al-Fatih. Jakarta.

Anonymous. 2012. Al-Qur'anul Karim: Tafsir Kata Tajwid Kode. The Holy Qur'an Al Fatih. Terjemahan Surat Al-Muthaffifin Ayat 1-6. Al-Fatih. Jakarta.

Anonymous. 2012. Al-Qur'anul Karim: Tafsir Kata Tajwid Kode. The Holy Qur'an Al Fatih. Terjemahan Surat At-Taubah Ayat 20 Ayat 1-6. Al-Fatih. Jakarta.

Bek, A. 2009. al-Mu'amalah asy-Syar'iyah al-Maliyah (Kairo: Dar al-Intishar, t. th). Minhajuddin, Fiqh tentang Muamalah Masa Kini. Fakultas Syariah IAIN Alaudddin. Ujungpandang.

Burrell, G. dan G. Morgan. 1979. Sociological Paradigms and organisational Analysis - Elements of the Sociology of Corporate Life. Sociological Paradigms and Organisational Analysis, 1-37. http://doi.org/10.1177/003803858001400219

Husserl, E. 2001. The Idea of Phenomenology. Kluwer Academic Publishers vol. VIII, terj. Lee Hardy, Boston. 
Tranparansi

dan

Akuntabilitas

Pelaporan...

638
Ikatan Akuntansi Indonesia. 2010. Standar Akuntansi Keuangan. Salemba Empat. Jakarta.

Ikatan Akuntan Indonesia. 2012. Standar Akuntansi Keuangan. Ikatan Akuntan Indonesia (IAI). Jakarta.

Krisyanto, R. 2007. Teknik Praktis Riset Komunikasi. Kencana. Jakarta.

Moleong, L.J. 2006. Metodologi Penelitian Kualitatif. PT. Remaja Rosdakarya. Bandung.

Munawwir, A.W. 2003. Kamus Arab-Indonesia Cetakan XIV. Pustaka Progressif. Surabaya.

Ikatan Akuntan Indonesia (IAI). 2011. Pernyataan Standar Akuntansi Keuangan (PSAK) No. 45 Tahun 2011 tentang Organisasi Nirlaba. Ikatan Akuntan Indonesia (IAI). Jakarta.

Pemerintah Provinsi Jawa Timur. 2017. Surat Keputusan Gubernur No. 188/288/ KPTS/013/2016 tanggal 22 April 2016 yang telah diperbarui dengan Surat Keputusan Gubernur No. 188/147/KPTS/013/2017 tanggal 17 Maret 2017 tentang Badan Pengelola Masjid Nasional Al Akbar Periode 2016-2019.

Triyuwono, I. 2006. Akuntansi Syariah. PT Raja Grafindo Persada. Jakarta. 